\title{
Preparation of Ultra-Fine Grained Alloys Based on Fe-Al-Si And Ti-Al-Si Intermetallic Com- pounds by Powder Metallurgy Using the Mechanical Alloying
}

Jiř́i Vystrčil, Pavel Novák, Alena Michalcová

University of Chemistry and Technology, Prague, Department of Metals and Corrosion Engineering, Technická 5, 166 28 Prague 6, Czech Republic, E-mail: vystrcil.jiri@volny.cz; panovak@vscht.cz; michalca@vscht.cz

\begin{abstract}
Alloys based on the intermetallic phases are presently considered to be very promising materials for demanding technological applications in a wide range of industries. The biggest disadvantage of intermetallics is their low toughness at room temperature. One of the way how to increase their plasticity and eliminate susceptibility to low temperature brittleness is preparing intermetallic phases with ultrafine grain structure. The paper describes the preparation of ultra-fine grained alloys based on intermetallic phases by mechanical alloying and subsequent compaction by the "Spark Plasma Sintering" (SPS). Influence of the individual alloy components on the preparation and mechanical properties of intermetallics alloys were studied. The basic mechanical properties at room and elevated temperatures, resistance to high temperature oxidation and thermal stability of alloys were measured.
\end{abstract}

Keywords: powder metalurgy, mechanical alloying, intermetallics, ultra-fine grained

\section{Acknowledgement}

This research was supported by Czech Science Foundation, project P108/12/G043.

\section{References}

[1] STOLOFFA, N. S., LIUB, C. T., DEEVIC, S. D. (2000). Emerging applications of intermetallics. In: Intermetallics, Vol. 8, pp. 1313-1320. Elsevier. Netherlands.

[2] FROES, F. H., SURYANARAYANA, C., ELIEZER, D. (1992). Synthesis, properties and applications of titanium aluminides. In: Journal of Materials Science, Vol. 27, No. 19, pp. 5113-5140. Kluwer Academic Publishers Netherlands.

[3] DEEVI, S. C., SIKKA, V. K., LIU, C. T. (1997). Processing, properties, and applications of nickel and iron aluminides. In: Progress in Materials Science, Vol. 42, pp. 177-192. Elsevier. Netherlands.

[4] MORRIS, D. G., MORRIS-MUNOZ, M. A. (1999). The influence of microstructure on the ductility of iron aluminides. In: Intermetallics, Vol. 7, No. 10, pp. 1121-1129. Elsevier. Netherlands.

[5] NOVÁK, P., MICHALCOVÁ, A., ŠERÁK, J., VOJTĚCH, D., et al. (2009). Preparation of Ti-Al-Si alloys by reactive sintering. In: Journal of Alloys and Compounds, Vol. 470, pp. 123-126. Elsevier. Netherlands.

[6] NOVÁK, P., KNOTEK, V., VODĚROVÁ, M., KUBÁSEK, J., ŠERÁK, J., MICHALCOVÁ, A., VOJTĚCH, D. (2010. Intermediary phases formation in Fe-Al-Si alloys during reactive sintering. In: Journal of Alloys and Compounds, Vol. 497, pp. 90-94. Elsevier. Netherlands.

[7] NOVÁK, P., KUBATÍK, T., VYSTRČIL, J., HEDRYCH, R., KŘÍŽ, J., MLYNÁR, J., VOJTĚCH, D. (2014) Powder metallurgy preparation of Al-Cu-Fe quasicrystals using mechanical alloying and Spark Plasma Sintering. In: Intermetallics, Vol. 52, pp. 131-137. Elsevier. Netherlands.

[8] GONG, J., ZHAO, Z., YANG, Y., GUAN, Z., MIAO, H. (2011). Statistical variability in the indentation toughness of TiCN particle reinforced $\mathrm{Al}_{2} \mathrm{O}_{3}$ composite.In: Materials Letters, Vol. 46, No. 6, pp. 357-360. Elsevier. Netherlands. 